\title{
Training and Development impact on Organizational Performance: Empirical Evidence from Oil and Gas Sector of Pakistan
}

\author{
Hassan Raza \\ Foundation University Rawalpindi Campus
}

\begin{abstract}
The study objective is to investigate the relationship between the training and development strategies and its impact on organizational performance. To quantify this relationship, primary data was collected. The regression analysis was done on the employees of oil and gas sector of Pakistan. The finding of the study revealed the situation of training and development in Pakistan and showed that majority of the employees satisfied with the strategic $T \& D$ of the firm. The findings helped the management to concentrate towards the $T \& D$ as to improve the required skills of the employees which are important for the organizational performance. For conducting the effective training outcomes the study must be done more frequent.
\end{abstract}

\section{Introduction}

In the prevailing scenarios, employee training and their development have outmost importance for the sake of improving the productivity, which leads towards gaining competitive advantage (Quartey, 2012). However, employee training is considered as the planned step towards facilitating employees to seek jobrelated knowledge including behaviors and skills (Dennis and Griffin, 2005). In human resource development (HRM) the theories and empirical evident supports Training and Development as strategic positioning which have a direct relationship with development and achieving goals precisely.

The training and development of the employees has direct contributions in the high achievements of organization which shows better performance. Training increased the organizational performance which predicted by many researches (Peteraf, 1993; Niazi, 2011). Performance of an organization is defined as how effective and efficient managers use organizational resources to satisfy customers and achieve organizational goals and objectives. Ideally, the more employees are trained and are satisfied with their work and environmental conditions, the more they can help enhance their organizations' performance.

The resource based view theory supported that any training designed for the organization is based on the creation of values and enhancing the capabilities for continued organization performance (Barney, 1991). In Pakistan the recent changes in the policies of trades and the globalization surrounded by fierce competition, the oil and gas sector being the largest distributor in GDP renewing and re-emphasizing their focus on training and development. There is continues hike in the demand of oil and gas in Pakistan being a developing country.

\section{Problem statement}

In this scenario, this study sought to analyze the impact of employee training and development on the oil and gas sector performance.

\section{Objectives of the study}

The objective if the study is to check the impact of training and development on the organizational performance particularly in the oil and gas sector of Pakistan. The oil and gas sector was selected as being the major industry acts as the backbone of the Pakistan's economy where there is much opportunity of foreign investment.

\section{Applied aspects \\ The significance of the study is broadly classified in to two parts. In practical HRM the study will help the managers to understand the impact of training and development on employees and to make policies accordingly. Whereas at theoretical level, it helps to design policies and strategies about training and development of employees, which ultimately effect the organizational performance. The data collected from the oil and gas sector of Pakistan which leads towards developing understanding of oil and gas sector performance.}

Research Question

Does the employee training and development affect the organization performance? 


\section{Literature Review}

Organizational performance and its growth depend upon the skills and knowledge of the employees which considered as the assets of the firm. The knowledge, development, abilities and skills are the dimensions of the process of training and development. However, the results of training impart major contribution in the better performance therefore, considered at strategic level in the organizations. To understand the training and development the literature review is carried out in three facets one is to understand the organizational performance, second to elaborate the strategic training and developments and its process and the last is training need in employees and its implementation.

\section{Organizational Performance}

The performance of the organization refers to those attitudes' that have been assessed or measured as to their contribution to organizational goals (Cook and Hunsaker, 2001). The behavior or attitude indicated the approach and skills of the management specially line management that helps them to use the resources' successfully and professionally with competency. However this competency is enhanced with the help of training and development.

\section{Strategic Training and Developments}

Tichy et al. (1982) studied the three major prospective of the organizational performance and one of them was human resources management. The other two prospective were mission and strategy of the firm and the organizational structure which gave direction to the workers. Further the study concluded that development of the employees is positively related with the performance of the workers as well as organizations.

Miles and Stone (1984) argued that the employees rarely participated in the proactive planning process in which they got training by focusing on the conceptualization and designing which were formulated to increase their capabilities. This results leads towards formation of new business strategies.

Hussey (1985) suggested that training of the organization should base on the strategy of the corporation. The empirical finding concluded that management training in UK is rarely relevant with the organization's objectives and the employees of the organization relates the training with their promotion or with individual skills. Collins et al. (2003) supported that the development in the employee's skills via training also reduced the employees turn over in the firm.

\section{Training Need in Employees and its Implementation}

Leicester (1988) identified three means for designing and aligning the strategy of training and development. The focus of the study was on the line manager development. The three phases included the employee's performance appraisal, development of the workers and creation of balance between the tasks and training that is further creating a link between the training and its requirement. However, Burney (1991) offered a theory of Resource based view in which the organization can achieve the competitive edge only on the base of its internal resources which included skills of the employees and knowledge etc. The organizations can maintained its performance by implementing the training at strategic level, and if they failed to implement strategies their internal capabilities will be exploited ( Barney, 2001). Dessler (2006) defined the training as giving new and different skills to the employees for performing their jobs. Armstrong (2009) suggests that" training can refer to the practice of equipping employees with skills, knowledge, and abilities, with the aim of building organizational capabilities and increasing increase organizational performance".

There are different approaches to the training which linked the learning in the organization with the strategic T\&D like Proactive Approach In which learning activities with the corporate business strategy and its focus is on developing competencies.

\section{THEORETICAL FRAMEWORK AND HYPOTHESIS GENERATION}

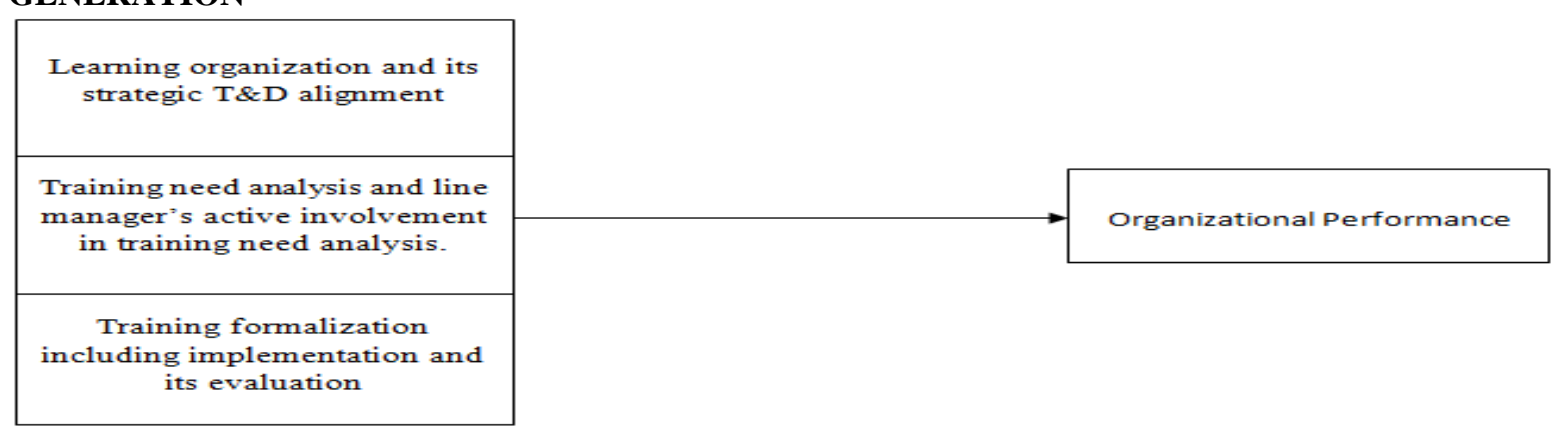




\section{Research hypothesis}

H1: Learning organization and its strategic T\&D alignment have a significant positive relationship with organizational performance.

H2: Training Need Analysis (TNA) and Line Manager's active involvement in TNA have a significant and positive relation with organizational performance.

H3: T\&D formalization including its implementation and evaluation have significant and positive relation with organizational performance.

\section{Data and Methodology}

The study is designed to investigate the relationship between the training and development strategies and its impact on organizational performance. To quantify this relationship, primary data was collected.

\section{Sampling procedure}

The population of the study included the employees of oil and gas sector of Pakistan. Convenient sampling technique was adopted through which the four major oil and gas companies were selected from KSE 100 index. The responses were collected from employees via using questionnaire. The adapted questionnaires were distributed by visiting the company or by sending through email.

\section{Employee survey}

Respondents of the research were line managers, or middle and top management of the companies. Total 200 questionnaires were distributed, out of which 154 returned in which 136 were completely filled. this shows response rate up to $68 \%$.

\section{Research Instrument}

The questionnaire was adapted from Naizi (2011) and Allen et al. (2007).

\section{Hypothesis testing}

There were 3 facets of training and development strategies, these were Learning organization and its strategic T\&D alignment (4 items), Training Need Analysis (4 items), Training formalization (3 items) and the organizational performance ( 3 items). Employees were considered for this survey. Interval scale were utilized in which response were collected on five point likert scale ranging from 5 strongly agree to 1 strongly disagree.

\section{Statistical Tool}

Primary data is collected from different level of employees and represented via descriptive statistics and detailed graphs. The adapted questionnaire is used. Hence the present study uses hierarchical linear modeling for presenting the data.

\section{Presentation And Analysis Of Data}

\section{Learning Organization \& Strategic T\&D alignment -H1}

To measure Learning Organization and planned T\&D alignment with the performance elevation 4 items were used. The questions were about employee's development by considering the company as a learning organization which provides training like strategic umbrella, which is aligned with the business objectives, availability of proper training directory and at the same time result in their improvement in achieving goals. These questions were designed to map out the T\&D alignment with organization performance. The finding revealed that there is positive impact of learning organization and training on the employees as $39 \%$ employees are satisfied while 19\% are strongly agreed as they are getting strategic planning and T\&D which is aligned with the objectives of the organization. Thus H1 hypothesis is accepted as shown by the results. The finding is consistent with Irene (2009) who also emphasized that training process impact on the employees and organizational performance when employee is considered as learner and organization considered $T \& D$ as outmost need by relating it with motivation and progress.

Table 4.1 showing the responses of employees regarding hypothesis 1.

\begin{tabular}{|c|c|c|c|c|c|c|c|}
\hline Item & $\begin{array}{l}\text { Strongly } \\
\text { disagree }\end{array}$ & disagree & Neutral & Agree & Strongly Agree & mean & SD** \\
\hline LO1 $*$ & 16 & 17 & 35 & 53 & 15 & 3.48 & 1.12 \\
\hline LO2 & 7 & 25 & 28 & 50 & 26 & 3.48 & 1.07 \\
\hline LO3 & 10 & 19 & 25 & 55 & 27 & 3.54 & 1.12 \\
\hline LO4 & 10 & 14 & 35 & 53 & 24 & 3.59 & 1.02 \\
\hline H1 & $8 \%$ & $14 \%$ & $23 \%$ & $39 \%$ & $16 \%$ & - \\
\hline
\end{tabular}

*Learning organization

** Standard Deviation 
Fig 4.1 Representation of Responses of $\mathrm{H1}$.

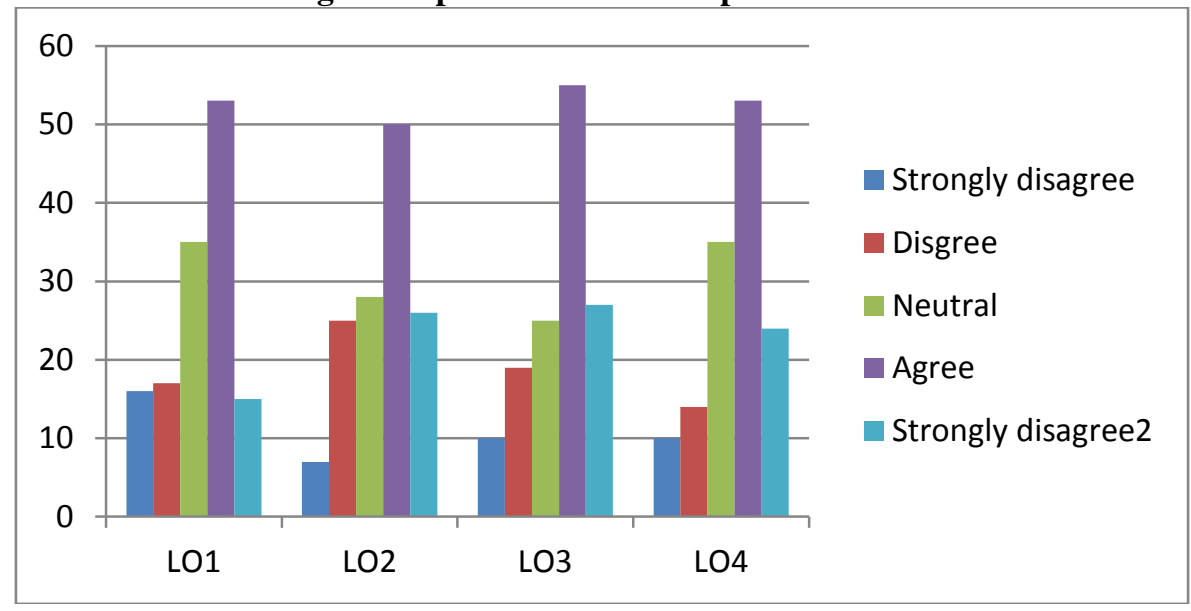

For further statistical analysis the average and standard deviation of the data is carried out. The mean of the variable shows that aligned $T \& D$ is little but it is present as mean value is 3.60 which are more near to positive response (table 4.1). The histogram (fig 4.1) also showing the relationship of responding of employees along the likert scale.

\section{Training Need Analysis (TNA) and Line Manager's active involvement- H2}

The second hypothesis of the study was tried to verify training need analysis and how much the line management occupied to it. To quantify the above hypothesis 4 items were used. The questions were about the training need analysis and its impact on the performance and skills of the employee as well as cost benefit to the organization. The finding disclosed that $37 \%$ employees are agreeing and $12 \%$ are strongly agreed. While $26 \%$ have neutral in their response (Table 4.2).

The result shows that training program must be relevant to the organizational objectives as to create the interest of the trainees as well as cost benefit for the firm. The interest and benefit of the firm and employees are the outmost requirement of the training programmed which is the resultant of TNA.

Table 4.2 showing the responses of employees regarding hypothesis 2.

\begin{tabular}{|c|c|c|c|c|c|c|c|}
\hline Item & $\begin{array}{l}\text { Strongly } \\
\text { disagree }\end{array}$ & disagree & Neutral & Agree & $\begin{array}{l}\text { Strongly } \\
\text { Agree }\end{array}$ & mean & SD** $^{* *}$ \\
\hline TNA1 & 20 & 24 & 34 & 37 & 21 & 3.32 & 1.153 \\
\hline TNA2 & 9 & 15 & 36 & 50 & 26 & 3.40 & 1.028 \\
\hline TNA3 & 6 & 25 & 38 & 53 & 14 & 3.37 & 1.017 \\
\hline TNA4 & 6 & 15 & 40 & 65 & 10 & 3.46 & 0.894 \\
\hline H2 & $7 \%$ & $16 \%$ & $26 \%$ & $37 \%$ & $12 \%$ & - & - \\
\hline
\end{tabular}

*Training Need Analysis

** Standard Deviation

The histogram (fig 4.2) also showing the relationship of responding of employees along the likert scale.

Fig 4.2 Representations of Responses of $\mathrm{H2}$.

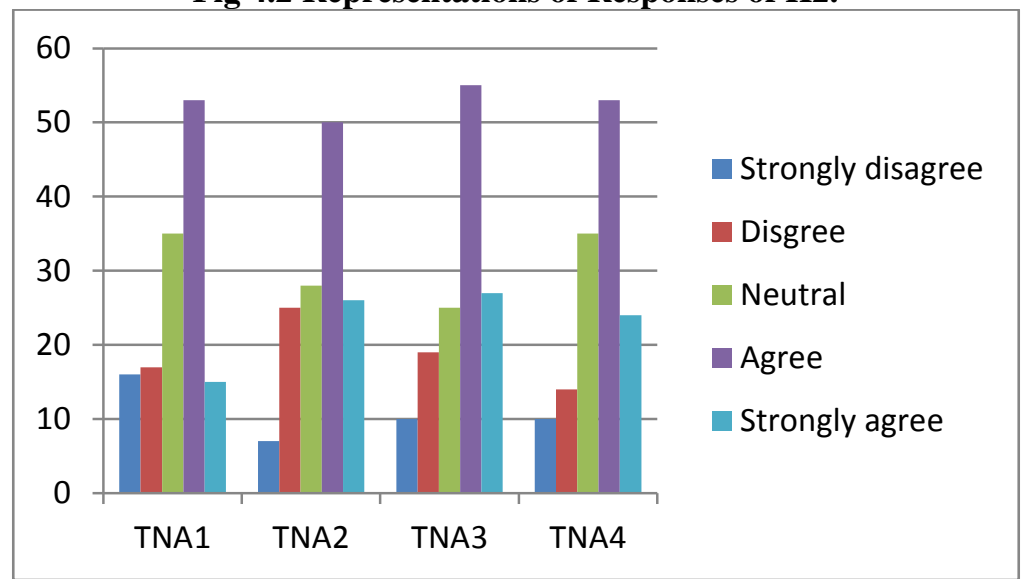

Training Formalization Including Accomplishment and Its Assessment 
The third hypothesis of the present study was about the training designing including proper accomplishment and its assessment. Three items were included in the questionnaire comprising the dimensions of training formulation. The questions were about the satisfaction of the employees from the training programs of the firm, the opportunities available to the as a resultant and about the counseling in the organization. The result revealed that $35 \%$ employees are satisfied from the training formulations and $15 \%$ are strongly agreed with the organization. While $18 \%$ are disagree and $24 \%$ are neutral in their opinion (table 4.3 ).

Table 4.3 showing the responses of employees regarding hypothesis 3 .

\begin{tabular}{|c|c|c|c|c|c|c|c|}
\hline Item & $\begin{array}{l}\text { Strongly } \\
\text { disagree }\end{array}$ & disagree & Neutral & Agree & $\begin{array}{l}\text { Strongly } \\
\text { Agree }\end{array}$ & mean & SD** \\
\hline $\mathrm{TF}^{*} *$ & 6 & 23 & 35 & 53 & 19 & 3.46 & 1.03 \\
\hline $\mathrm{TF} 2$ & 12 & 28 & 31 & 41 & 24 & 3.40 & 1.13 \\
\hline $\mathrm{TF} 3$ & 10 & 23 & 34 & 50 & 19 & 3.35 & 1.09 \\
\hline $\mathrm{H} 3$ & $6.8 \%$ & $18 \%$ & $24 \%$ & $35 \%$ & $15 \%$ & - & - \\
\hline
\end{tabular}

$* T F$ training formulation

** Standard Deviation

Fig 4.3 Representations of Responses of $\mathrm{H3}$.

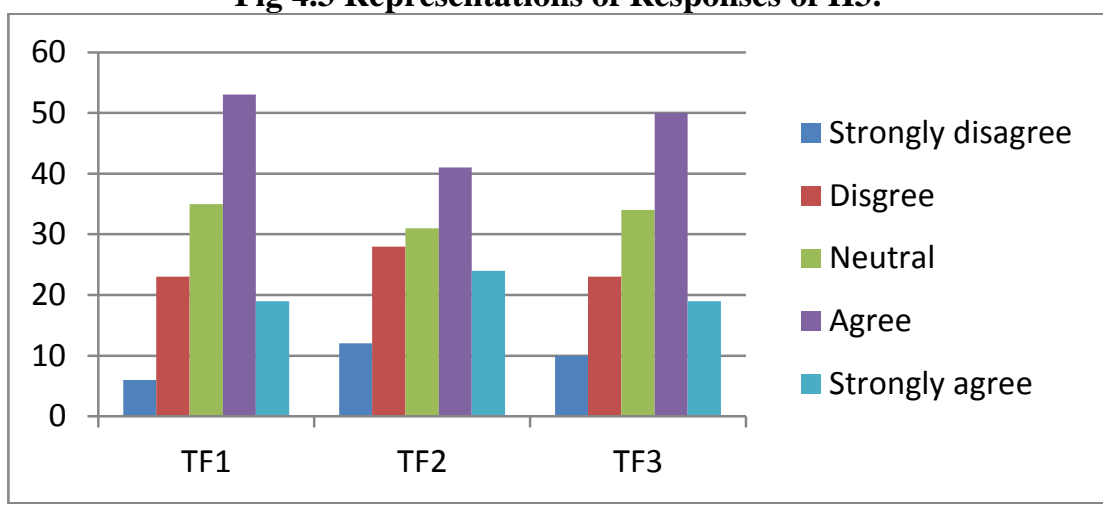

The histogram (fig 4.3) also showing the relationship of responding of employees along the likert scale. This shows that oil and gas sector is vigilant in grooming their employees. The mean of the data is also slightly above the neutral. Hence the $\mathrm{H} 3$ also accepted showing that training formulation if up to the market challenges they increase the organizational performance. These results are consistent with Delery and Doty (1996).

\section{Conclusion}

The Employee Strategic T\&D in the organizations as exemplify by Oil and Gas industry has been the focal point of this study. The finding of the study revealed the situation of training and development in Pakistan and showed that majority of the employees satisfied with the strategic T\&D of the firm. There are very few organizations which fulfilled the demand with reference to the requirements of strategic T\&D. This leads towards widening the gaps between the required skills and the attained skills of the employees. These circumstances are disturbing the balance and equilibrium of better performance in HRM and development via T\&D. Therefore, to fulfill this gap companies are giving attention on the training and implementing a high level roadmap for strategic $T \& D$.

The learning organization in the developed countries considered as corporate universities having best learning practices. The environment of such organizations made the learning culture and improves the performance of the employees. In Pakistan, the oil and gas sector also giving attention towards promoting learning culture in the organizations.

Line Managers are accounted for making reports, so their involvement in the strategic T\&D is very helpful as the study results indicated. The improvement in the workforce skills for the benefit of organizational performance contains outmost importance. The focus of the program is to develop the career and job skills in the line management which must be relevant with the objectives of the firm.

It is the need of the time to enhance and sharpen the skills of the human capital in the organizations. Employees grooming is considered as the social as well as moral obligation for the organizations. The skilled employees increase the performance and helped to attain the goal.

In the global world, the fierce competition encourages the firms to adopt the strategic approaches of T\&D to augment the firm's performance. The findings of the study also showed that firms which adopted the 
strategic T\&D, their employees are more skilled and performance is also better. The satisfied work force is the asset for the firm which positively contributes towards the objectives.

\section{Recommendations}

The findings helped the management to concentrate towards the T\&D as to improve the required skills of the employees which are important for the organizational performance. The government should make policies as the better performance of the industries will impart major role in the economy of the country as well as in the social sector.

\section{Limitations}

Furthermore, to achieve the effective results training must be frequent.

\section{References}

[1]. Allen, R.S., Dawson, G., Wheatlay, K. \& White, S.C. (2007), Perceived diversity and organizational performance. Employee Relations, 30(1), pp.20-33.

[2]. Armstrong, M. (2009), “A handbook of Human Resource Management Practice,” (10th ed.), London: Kogan Page Limited.

[3]. Barney, J. B. (1991), "Firm resource and sustainable competitive advantage," Journal of Management, 17 (1), 99-120.

[4]. Barney, J. B. (2001), "Is the resource-based view a useful perspective for strategic management research? Yes," Academy of Management Review, 26(1), 41-56.

[5]. Collins, C., Buhalis, G., and Peters, F. (2003), "Enhancing SMTEs business performance through the internet and e-learning platform," Education and Training, 45(8/9), 483 - 494.

[6]. Cook, C. W., and Hunsaker, P.L. (2001), "The Management and Organization Behaviour," (3rd ed.), New York: McGraw- Hill

[7]. Delery, J. E. \& Doty, D. H. (1996), "Models of theorizing in strategic human resource management: Tests of universalistic, contingency, and configurational performance predictions," Academy of Management Journal, 39, 802-835.

[8]. DeNisi, A.S., and Griffin, R.W. (2005), "Human Resource Management," Boston, NY, Houghton Mifflin Company

[9]. Dessler, G. (2000), "Human Resource Management," Prentice Hall, 8th Edition.

[10]. Hussey, D.E. (1985), "Implementing corporate strategy and change: using management education and training", Long Range Planning, Vol. 18 No. 5, pp. 23-37.

[11]. Irene, F.L. (2009), "A Thesis on the Impact of Training and Development on the Worker Performance and Productivity in the Public Sector Organizations: A case study of Ghana Ports and Harbours Authority,”_～(Submitted Thesis), Institute of Distance Learning: KNUST

[12]. Leicester, C. (1988), "Employee development strategies: the basic analysis", Future Employment Issues, Discussion Paper No. 7, University of Sussex.

[13]. Miles, R.E. and Snow, C.C. (1984), "Designing strategic human resources systems", Organisational Dynamics, Vol. 13, Part 8, pp. 36-52.

[14]. Niazi, A.S. (2011), "Training and Development Strategy and Its Role in Organizational Performance," Journal of Public Administration and Governance, 1(2), 42-57.

[15]. Peteraf, M. A. (1993), “The Cornerstones of Competitive Advantage: A Resource-Based View," Strategic Management Journal, 14(3), 179-192.

[16]. Quartey, S. H. (2012), Effect of Employee Training on the Perceived Organisational Performance: A Case Study of the Print-Media Industry in Ghana, European Journal of Business and Management, 4(15), pp,77-88

[17]. Tichy, N.M., Fombrun, C.J. and Devanna, M.A. (1982), "Strategic human resource management", Sloan Management Review, Winter , pp. 47-61. 